\title{
GEOFFREY HOLT
}

As a member of its Council, Fr. Geoffrey Holt, SJ, scholar and historian, has helped to guide the business of the Catholic Record Society for over a quarter of a century, the last six years in the capacity of one of its vice-presidents.

Born on 27 April 1912 and educated at Stonyhurst College, he entered the Society of Jesus shortly following his eighteenth birthday, read modern history at Oxford, was ordained to the priesthood at the close of the Second World War and made his last vows in 1951. A twenty-year apostolate of teaching history ensued at two of the Society's most prestigious schools in the then English Province, Mount St. Mary's and Stonyhurst. Subsequently he joined the community at the Jesuit headquarters in London where he has now spent over thirtyfive years in writing and working in the Province archives, for some of the time as archivist.

Fr. Holt's interests in ecclesiastical history are mainly centred upon research into the seventeenth and eighteenth centuries. The CRS issued his Sabran Letter Book in 1971 (CRS volume 62), St. Omers and Bruges Colleges in 1979 (CRS volume 69) and English Jesuits 16501829 in 1984 (CRS volume 70). Based upon original source material, his William Strickland and the Suppressed Jesuits was published in 1988 and the important subsequent volume, The English Jesuits in the Age of Reason, in 1993. Fr. Holt has published numerous papers and articles in a wide variety of scholarly journals. Here we print his latest contribution, constituting a valuable sidelight on aspects of ecclesiastical history of the mid-eighteenth century.

This edition of Recusant History reflects Fr. Holt's range of historical attention and, as he celebrates a significant birthday, it forms a measure of appreciation from the CRS and fellow researchers in the field.

V.A. McClelland 